Published 11 October 2018 in Music \& Letters 99, no. 3, pages 448-70: https://academic.oup.com/ml/articleabstract/99/3/448/5127378? redirectedFrom=fulltext

This document contains the post-print version.

\begin{abstract}
The 'intentional fallacy' and pronouncements of the 'death of the author' supported the hermeneutical flights of fancy that characterized the 'New Musicology' of the 1980s and early 1990s, but mesh less well with more recent New-Historicist impulses. Anti-intentionalism is motivated by a belief in the autonomy of art, a belief most musicologists today reject. Our interest in composers' working documents and correspondence also conflicts with antiintentionalist methodologies. Due to the diversity of current musicology, no one stance towards interpretation is going to describe all interpretative activities in our field. Nevertheless, for those interested in understanding musical works and performances as the products of human endeavour, I argue that moderate actual intentionalism is the theory that best describes practices directed towards this aim. Its chief advocates-Paisley Livingston, Robert Stecker, and Noël Carroll—are philosophers in the analytic tradition. This article, thus, provides a glimpse of what musicology might gain from taking a greater interest in work in this field.
\end{abstract}




\section{Intentions in Theory and Practice}

Nina Penner*

The 'intentional fallacy' and pronouncements of the 'death of the author' supported the hermeneutical flights of fancy that characterized the 'New Musicology' of the 1980s and early 1990s. Under the influence of New Historicism, the discipline has taken a more rigorous approach to history in the intervening years. In spite of an increased concern with the doings of historical agents, anti-intentionalist inclinations persist.1 Musicologists adverting to composers' or musicians' intentions are still apt to be called out for committing either the intentional or poietic fallacies.

The latter is an idea peculiar to musicology, coined by Richard Taruskin in 2004. Since then, Taruskin has used it to punish a variety of musicological sins, chief among these being the privileging of the process of creation, particularly the composer's intentions, over that of reception. 2 The former is a relic of New Criticism. In a now famous essay of 1946, literary critic William K. Wimsatt and philosopher Monroe C. Beardsley argued that authors' intentions are irrelevant to determining either the meaning or the artistic value of literary works.3 As their argument goes, either the author's intentions are successfully realized in the text, in which case it is not necessary to consult them, or they are not, and thus do not inform us about the text. For Wimsatt and Beardsley, the intentional fallacy was a means of directing literary criticism to what

* Trevor Ponech first suggested to me the idea of writing a defence of moderate actual intentionalism for a musicological readership. My thoughts on intentions and their role in the appreciation of music have been refined through many productive conversations with Edmund Goehring. Paisley Livingston, Cathy Shuman, Lloyd Whitesell, and Steven Huebner have also offered valuable feedback on earlier drafts of this paper. Finally, I am grateful to the anonymous reviewers for their incisive criticisms and suggestions. 1 Also observed by Jeremy Coleman, 'Wagner in Paris: Translation, Identity, Modernity' (Ph.D. diss., King's College London, 2016), 15.

2 Richard Taruskin, 'The Poietic Fallacy', Review of Arnold Schoenberg's Journey by Allen Shawn, Musical Times, 145 (2004), 7-34 at 10-11. See also his Oxford History of Western Music, vol. 2 (Oxford, 2005), 13; 'The Danger of Music and the Case for Control', in The Danger of Music and Other Anti-Utopian Essays (Berkeley, CA, 2009), 168-80 at 178 .

3 William K. Wimsatt and Monroe C. Beardsley, 'The Intentional Fallacy', Sewanee Review, 54 (1946), 468-88. 
they regarded as the proper object of appreciation: the text itself. Their anti-intentionalist stance was, thus, motivated by their belief in the autonomy of literature, a belief that what really matters is the words on the page, not how or why they got there.

At the mention of the autonomy of art, it should be clear that Wimsatt and Beardsley's stance towards the aims of art criticism is wildly divergent from those of New-Historicist musicology. Even the New Musicology was ostensibly aimed at recuperating the social and political dimensions of music that were overlooked in the discipline's former focus on philological concerns and New-Critical-style formalist analysis. If musicology continues to take an interest in questions about how and why musical works and performances sound the way they do, why does 'intention' continue to be a bad word in musicological discourse? Why the continued belief in the intentional fallacy when the discipline has long since rejected the premise on which it is based? 4

One part of this puzzle is a tacit assumption that a commitment to intentionalism must be all or nothing: either the artist's intentions fully determine the work's meaning (absolute intentionalism) or they have no relevance to interpretation (extreme anti-intentionalism). Observing that artists are just as fallible as everybody else, and that an exclusive focus on the artist can obscure the social and political dimensions of art, the latter stance would seem to be the only viable option. Yet, if one wishes to regard the participants in the musical milieus we study as historical agents, one cannot avoid taking an interest in the intentions motivating their actions.

Another reason for the persistence of anti-intentionalism, despite its incongruence with the broader aims of the discipline, is that alternatives lie in an area not well-travelled by 
Anglophone musicologists: analytic aesthetics. Although musicology has become increasingly interested in philosophy within the past decade, the discipline has taken little notice of work by philosophers on their own campuses, which primarily lies in the analytic tradition. Meanwhile, analytic philosophers are taking note of current work in musicology. Whereas philosophers like Peter Kivy often mentioned musicology simply to critique it, more recent work in analytic aesthetics is using musicological findings as the basis on which to found more historically situated accounts of the nature of musical works and performances.5

This paper provides a glimpse into what musicology might gain from reciprocating this interest. Specifically, analytic philosophy can offer musicology a more robust framework for thinking about the nature of intentions and their role in interpreting and appreciating musical works and performances. After establishing a conflict between theory and practice concerning authorial intentions in both the New Musicology and more recent work in the discipline, I survey leading stances towards intentions and interpretation in philosophy. Due to the diversity of current musicology, no one stance is going to describe all interpretive activities in our field. Nevertheless, for those interested in understanding musical works and performances as the products of human endeavour, I argue that moderate actual intentionalism is the theory that best describes musicological practices directed towards this aim.

5 See, for example, Peter Kivy, 'Absolute Music and the New Musicology', in New Essays in Musical Understanding (Oxford, 2001), 155-67; 'Action and Agency', in Antithetical Arts: On the Ancient Quarrel between Literature and Music (Oxford, 2009), 119-56; 'Authorial Intention and the Pure Musical Parameters', in Sounding Off: Eleven Essays in the Philosophy of Music (Oxford, 2012), 191-209 at 194. Representative of a more egalitarian relationship between analytic aesthetics and musicology is John Dyck, 'Perfect Compliance in Musical History and Musical Ontology', British Journal of Aesthetics, 54 (2014), 31-47. For a defence of recent work in the philosophy of music (mostly in the analytic tradition) against accusations of ahistoricism, see Tomas McAuley, 'Missing the Wrong Target: On Andrew Bowie's Rejection of the Philosophy of Music', Performance Philosophy, 1 (2015), 5964. 
Authorial Intentions and the New Musicology

Among other changes to the discipline, the New Musicology ushered in a new-found scepticism regarding the relevance of the composer's intentions to interpretation, even while it insisted on studying music 'in context'. Representative of both impulses, and the ways they pull apart, is Carolyn Abbate's Unsung Voices (1991). In the Preface, Abbate remarks that '[m]usic critics, analysts, and theorists often either imply or state outright that their "words about music" represent "what the composer" or "what musicians at the time" considered significant in a given work, thus at once invoking an authority that is not completely ours to possess and adopting a "poietic" or "emic" strategy (reconstruction of the cultural or historical context that determined the work's production) to buttress interpretation.' Rejecting an intentionalist approach would seem to lead Abbate to something approximating New Criticism, by which one 'push[es] aside genetic or historical considerations, and rest[s] content in the faith that a particular analysis addresses some quality or configuration immanent in the work, a configuration subject only to a process of discovery that - though mediated by and couched in verbal terms - is assumed to be uncorrupted by culture or language.' 6 Yet, she rejects formalist approaches as well on grounds that they are insufficiently historical.

It is this interest in history that led critics like Abbate and Taruskin to continue to take an interest in composers' intentions even while maintaining an official rejection of such interpretive manoeuvres. In Taruskin's review of Unsung Voices, he chides Abbate for failing to fully embrace a postmodernist, listener-focused stance by continuing to rely on composers' sketches and 'superfluous statements of intention'.7 Indeed, Abbate quotes from Mahler's letters in her

${ }_{6}$ Carolyn Abbate, Unsung Voices: Opera and Musical Narrative in the Nineteenth Century (Princeton, NJ, 1991), pp. xiv-Xv.

7 Richard Taruskin, 'She Do the Ring in Different Voices', Review of Unsung Voices by Carolyn Abbate, Cambridge Opera Journal, 4 (1992), 187-97 at 188, quotation from 192. 
interpretation of his Second Symphony, refers to Wagner's sketches in connection with her argument about Tannhäuser's Rome Narrative, and provides an extended discussion of the evolution of the composer's intentions concerning what eventually became his Ring cycle. 8

An even more convincing case of conflicting impulses may be laid against Taruskin. He has not only been the most vigilant policeman of violations of the poietic fallacy but also one of its chief perpetrators. 9 At a time when the concept of bitonality was generally believed to be of questionable theoretical value, Taruskin advocated for a bitonal (as opposed to octatonic) analysis of the Petrushka chord (a combination of C major and F\# major triads) on intentionalist grounds. Here is his justification:

I believe something of the sort was very much on Stravinsky's mind when he wrote his Konzertstück [the origins of the second tableau of the ballet]. His harmony is animistic; the Petrushka chord is conceived, nay motivated, by a sense of struggle, an antagonism of order and chaos reflecting the roles of pianist $v s$. orchestra. Once again I wish to emphasize that there is practical and poetic-if not 'theoretical' — validity in the 'polytonal' idea. We are meant to hear C and F\# in terms of an active, not static, polarity - as competing centers, not merely as docile components of a single, static, octatonically referable 'hyper-harmony'.10 (emphasis added)

Taruskin's conviction that analysis should be informed by the theoretical concepts that guided the compositional process (as opposed to ones that postdate the work's composition or that would have been otherwise unfamiliar to the composer) has often set him against dominant

8 Abbate, Unsung Voices, 124, 264n34, 157-65.

9 Also noted by Friedemann Sallis, Music Sketches (Cambridge, 2015), 5.

10 Richard Taruskin, 'Chez Pétrouchka: Harmony and Tonality chez Stravinsky', 19th-Century Music, 10 (1987), 265-86 at 283. 
modes of analysis in North American music theory. For instance, he has criticized Allen Forte's analysis of Le sacre du printemps on grounds that 'the composer's ideas of significance and coherence were not congruent with those of [Forte's analysis]. ... Unless such congruence can be established, unless a measure of understanding is reached as to what the composer thought he was about, analysis cannot be said to have taken place at all.' Forte's method might be appropriate to the analysis of soil samples or weather patterns. However, '[a] piece of music is not a phenomenon of nature, but the product of human volition and the agent of human communication.' As such, Taruskin argues, it demands a different approach, one that is attentive to the composer's 'habits, routines, beliefs and aesthetic assumptions.' 11

The composer's intentions also influence Taruskin's assessments of artistic value. Upon discovering that Stravinsky's unorthodox approach to text setting was not a product of his poor grasp of the English language but an intentionally cultivated aesthetic effect, Taruskin proposed a reassessment of this aspect of Stravinsky's artistic practice.12 Through his study of the composer's sketches, he uncovered evidence that Stravinsky initially composed passages of the Three Japanese Lyrics (on Russian texts) with 'correct' prosody and subsequently misaccentuated the melody by shifting it with respect to the metre. Although one can criticize the effect of Stravinsky's choices on aesthetic grounds, one cannot charge him with ineptitude.

At this point, one might be concerned that these violations of the poietic fallacy come from the early part of Taruskin's career, before he even coined the phrase. Taruskin's theoretical stance towards interpretation has become more aggressively anti-intentionalist.13 Yet, his

\footnotetext{
11 Richard Taruskin, 'Letter to the Editor from Richard Taruskin', Music Analysis, 5 (1986), 313-20 at 318. Taruskin reiterates these criticisms in 'Catching up with Rimsky-Korsakov', Music Theory Spectrum, 33 (2011), 169-85 at 180 .

12 Richard Taruskin, 'Stravinsky’s "Rejoicing Discovery” and What It Meant: In Defense of His Notorious Text Setting', in Ethan Haimo and Paul Johnson (eds.), Stravinsky Retrospectives (Lincoln, NE, 1987), 162-200. 13 In his early essay 'Musorgsky vs. Musorgsky: The Versions of Boris Godunov', 19th-Century Music, 8 (1984), 91118 at $115 \mathrm{n} 2$, Taruskin even cites the absolute intentionalist E. D. Hirsch.
} 
methods have not undergone a similar swerve away from intentionalist arguments. Later on in this essay, I discuss Taruskin's recent reliance on Prokofiev's intentions in his interpretation of the Symphony-Concerto, Op. 125 (1952).14

These conflicts between theory and practice result from musicologists' rejection of the motivating premise for anti-intentionalism: the autonomy of art. Taruskin, especially, has been a vehement opponent of efforts to divorce music from the social and political circumstances of its creation.15 Nevertheless, anti-intentionalism remained attractive to many New Musicologists because it supported their interest in close readings, relatively unfettered from concerns about whether such readings were actually entertained by anyone before now.

Abbate may advert to Wagner's intentions and working processes when it suits her purposes, but ultimately Abbate's purposes take precedence. A case in point is her explanation for the reason why the final version of the Ring cycle contains so many seemingly superfluous scenes of narration. According to Abbate, Wagner was urging 'listeners to complete gaps and form our own supplementary stretches of libretto.' 16 As delightful as this idea may be to critics raised on Roland Barthes and Mikhail Bakhtin, it is dubious as an account of Wagner's creative decisions. As David Levin has remarked '[i]t is hard to think of an artist more opposed to the Bakhtinian ethos, more single-minded in his determination to close off the meaning of his

14 Richard Taruskin, 'What's an Awful Song Like You Doing in a Nice Piece Like This? The Finale in Prokofiev's Symphony-Concerto, Op. 125', Three Oranges, 20 (2010), 15-20.

15 This was another 'crime' Taruskin used his protean poietic fallacy to police. Richard Taruskin, 'Introduction: Taking It Personally', in On Russian Music (Berkeley, CA, 2008), 1-25 at 8; 'Speed Bumps', Review of Jim Samson (ed.), The Cambridge History of Nineteenth-Century Music and Nicholas Cook and Anthony Pople (eds.), The Cambridge History of Twentieth-Century Music, 19th-Century Music, 29 (2005), 185-207 at 194. Given that Taruskin has little interest in anachronistic interpretations, his belief in the intentional fallacy has other motivations. My inkling is that Taruskin's work on Stravinsky - notorious for his unreliable accounts of his working processesmade anti-intentionalism an attractive theory, especially if the alternative is perceived to be an approach that would force one to take such statements at face value.

16 Abbate, Unsung Voices, 161. 
librettos and reserve to himself the right to adjudicate that meaning.' 17 Abbate is not primarily motivated by a concern with what Wagner was attempting to do and whether or not he was successful but, rather, by a desire to put forth an interpretation that is personally satisfying. In philosophy, this approach is commonly referred to as 'value maximization'. For value maximizers, the meaning of a work is that which is most rewarding (aesthetically, politically, personally) to the critic, given certain limitations, such as consistency with the conventional meanings of words and stylistic features of the genre in question. 18

Value maximization was a common stance towards interpretation among New Musicologists. Another example is Susan McClary's interpretation of Brandenburg Concerto no. 5, mov. I.19 In what is now a conventional interpretive manoeuvre, McClary regards concerti as dramatizing the interaction between society (represented by the ripieno or full ensemble) and the individual (represented by the soloist[s]). Most examples from the Baroque era illustrate the compatibility of individualism and social stability through the orderly alternation of segments for the soloist(s) and ripieno, concluding with the latter's order-restoring ritornello.

Brandenburg Concerto no. 5 initially appears to be one for flute and violin, but soon the harpsichord emerges as a 'darkhorse competitor for the position of the soloist'. That the harpsichord would even be a contender is remarkable, McClary notes, as it was typically a 'service role' at this time.20 In this movement, however, the harpsichord asserts itself beyond its

17 David Levin, Richard Wagner, Fritz Lang, and the Nibelungen: The Dramaturgy of Disavowal (Princeton, NJ, 1998), 39.

18 For a definition and defence of value maximization, refer to Stephen Davies, 'Authors' Intentions, Literary Interpretation and Literary Value', British Journal of Aesthetics, 46 (2006), 223-47 at 242. Given that value maximizers define different limits to interpretive flexibility, it is not clear that Davies would support either Abbate's or McClary's interpretations.

19 Susan McClary, 'The Blasphemy of Talking Politics during a Bach Year', in Susan McClary and Richard Leppert (eds.), Music and Society: The Politics of Composition, Performance, and Reception (Cambridge, 1987), 13-62 at 23-4.

20 Ibid., 24, 25. 
station, 'and finally overthrows the other forces in a kind of hijacking of the piece', inserting an inordinately long solo capriccio in which it 'unleashes elements of chaos, irrationality, and noise until finally it blurs almost entirely the sense of key, meter, and form upon which eighteenthcentury style depends.' 21 Only then does it deign to allow the other instrumentalists to re-enter with the final ritornello. The rogue harpsichord's eventual yielding to the ripieno may appear to represent the individual submitting to the greater good of society, but McClary reflects that 'the subversive elements of the piece seem far too powerful to be contained in so conventional a manner.' She concludes by proposing that 'Bach is here enacting the exhilaration as well as the risks of upward mobility, the simultaneous desire for and resistance of concession to social harmony.' 22

The increasing conflict between emergent bourgeois individualism and social order, particularly under absolutism, was a growing concern of Enlightenment thinkers. Nevertheless, there is no evidence that Bach, a devout Lutheran, shared those concerns. Martin Luther believed in the necessity of social hierarchies in our earthly lives. All evidence suggests that Bach did as well. Bach scholar Michael Marissen observes that '[i]n his various clashes [with authority], Bach does not question the validity of contemporary hierarchies but, in fact, continually invokes his place in the hierarchy as part of his defense.' Notably, the most serious of these clashes were with 'authorities who espoused Enlightenment ideas.'23 Furthermore, Bach's comments in the margins of his Bible indicate that he believed that musical hierarchies were also 'part of the Godordained order of things in this world.' To explain why Bach decided to transgress those hierarchies in Brandenburg Concerto no. 5, Marissen draws attention to the Lutheran belief that

21 Ibid., 28, 36.

22 Ibid., 40, 41.

23 Michael Marissen, The Social and Religious Designs of J. S. Bach's Brandenburg Concertos (Princeton, NJ, 1995), 117. 
such hierarchies pertain only to this world, not to the world beyond. Thus, he argues that Bach's transgression does not indicate that he 'advocated or foresaw revolutionary action against contemporary social hierarchies' but rather that Bach was 'telling or reminding his listeners of the significant Lutheran viewpoint that such figurations have only to do with the present world and therefore are without ultimate significance.' 24

McClary and Marissen's disagreement about the meaning of Brandenburg Concerto no. 5 is rooted in a disagreement about the aims of interpretation. McClary initially states that her aims are 'to re-examine the ways in which Bach's music can be said to bear the imprint of its social origins, [and] to reconsider the place of Bach's music in present-day culture.'25 By the end of her article, it becomes clear that these endeavours pull in different directions, at least for McClary in this case, and that she is more interested in 'appropriat[ing] Bach to [her] own political ends' than understanding what, if any, political ends Bach was up to in Brandenburg 5.26 Marissen, by contrast, privileges the first of McClary's stated aims: understanding the actual historical influences over Bach's creative decisions. Such interests became more prevalent in musicology in the intervening years.

\section{New Historicism and Actor-Network Theory}

After the thrill of reading canonical works 'against the grain' began to wear off in the latter part of the 1990s, musicology became influenced by the broader intellectual movement known as New Historicism. Ellen Lockhart describes its manifestation in musicology as follows: 'the study of a musical culture, carefully delimited by years and geography, which proceeds by unearthing an abundance of now-forgotten pieces of music and making claims on their behalf, primarily by

24 Ibid., 114, 115.

25 McClary, 'Talking Politics', 14.

26 Ibid., 61. 
making connections to other literary, social, and scientific ephemera circulating in the same lifeworld.'27

One of central premises of New Historicism was rejection of the neat separation of 'text' from 'context', which had underpinned much of the New Musicology.28 Close reading was replaced by an impulse to collect objects, documents, and anecdotes. This impulse took musicologists away from canonical works and, in some cases, musical works altogether.29 Even so, many avowedly New-Historical contributions, including Lockhart's Animation, Plasticity, and Music in Italy, 1770-1830 (2017), are still concerned with interpreting musical works and performances.30 What differentiates their work from that of the previous generation is the range of materials scholars like Lockhart draw upon: not merely artistic artefacts and texts but also those from philosophy, science, and medicine.

To understand the role such objects had on musical milieus of the past, many musicologists look to actor-network theory. According to sociologist Bruno Latour, a leading voice in this discourse, 'any thing that does modify a state of affairs by making a difference is an actor'.31 The ability to perform self-impelled action is not required. Thus, the list of possible 'actors' in one's 'network' includes not only human beings and institutions - composers, performers, patrons, critics, publishers, concert organizers, record producers, arts agencies, and authors of various non-musical texts—but also non-human 'agents' like instruments, scores, recordings, concert venues, technologies, texts, and ideas.

27 Ellen Lockhart, 'Pygmalion and the Music of Mere Interest', Representations, 132 (2015), 95-103 at 96. 28 H. Aram Veeser, 'Introduction', in H. Aram Veeser (ed.), The New Historicism (London, 1989), pp. ix-xvi. 29 Nicholas Matthew and Mary Ann Smart, 'Elephants in the Music Room: The Future of Quirk Historicism', Representations, 132 (2015), 71-8 at 64.

30 Ellen Lockhart, Animation, Plasticity, and Music in Italy, 1770-1830 (Berkeley, CA, 2017).

31 Bruno Latour, Reassembling the Social: An Introduction to Actor-Network Theory (Oxford, 2005), 71. Actornetwork theory's chief musicological advocate is Benjamin Piekut, 'Actor-Networks in Music History: Clarifications and Critiques', Twentieth-Century Music, 11 (2014), 191-215. On the affinity between New-

Historicist musicology and actor-network theory, refer to Matthew and Smart, 'Future of Quirk Historicism', 67-8. 
Actor-network theory would seem to provide an answer to the problem of how to be a historian without speaking of the intentions of any actual agents. However, even if one accepts Latour's redefinition of the term 'agent', objects like scores and scientific theories can only make a difference when brought into contact with sentient beings capable of action. Phrases like 'kettles “boil” water' or 'hammers "hit" nails' are simply a more compact way of saying that a person may employ these tools and technologies to carry out these tasks.32 Scores and scientific theories cannot perform actions independently of persons. Ascribing agency to objects rather than to the persons who produced or interacted with them is not only misleading but, as Taruskin has cautioned, has the potential to rob these persons of agency, and thus responsibility for their actions.33

Creating music is an intentional endeavour, regardless of the myriad influences on its creation. Musicologists interested in understanding of those influences need a better account of what intentions are and the roles they play in the interpretation and appreciation of art.

\section{What Are Intentions?}

One of the reasons why debates about the latter question have been so unproductive is that participants have conflicting views concerning the former question. Anti-intentionalism as well as actor-network theory have been artificially bolstered by faulty assumptions about the nature of intentions. One such assumption is that to have an intention is necessarily to be conscious of it. We may be unaware of or even mistaken about some of the intentions motivating our actions

32 Latour, Reassembling the Social, 71.

33 Richard Taruskin, 'Agents and Causes and Ends, Oh My', Journal of Musicology, 31 (2014), 272-93 at 291-2. However, as Michael Gallope has observed, Taruskin 'circumvents the agency of individual composers' in his treatments of the postwar avant-garde in the Oxford History of Western Music. Furthermore, Taruskin's tendency to group together unlikely bedfellows (e.g., Adorno and Sartre) is 'somewhat misleading' 'on the level of what the individual agents did and said'. Michael Gallope, 'Why Was This Music Desirable? On a Critical Explanation of the Avant-Garde', Journal of Musicology, 31 (2014), 199-230 at 218, 222. 
without doubt being raised about whether those actions were intentional.34 Another is that to have an intention is necessarily to act on it, and to do so successfully. Intentions are subject to revision. Even when we decide to act, we may be unsuccessful in realizing our intention.

At present, one of the most lucid and detailed discussions of the nature of intentions in the creation and interpretation of art is philosopher Paisley Livingston's Art and Intention (2005). Drawing on work in the philosophy of action, particularly that of Alfred R. Mele, Livingston defines an intention as a particular attitude towards a plan of action. This attitude's specific nature is brought forth through a contrast with attitudes of desire and wanting: although intending and desiring both involve being motivated to do something, desire is not necessarily accompanied by being settled on doing that thing, or by a commitment to trying to do so. Nor is being settled on doing something the same as currently being preponderantly motivated to do that thing, since the lacking motivation may be brought in line with intention as the time for action approaches. In sum, to have the attitude of 'intending' towards a given plan is to be settled upon executing that plan, or upon trying to execute it. Being 'settled on' may be thought of, then, in terms of a firm yet defeasible form of commitment. 35

Livingston and Mele's definition contrasts with proposals that intentions are literally actions, such as John R. Searle's concept of 'intention in action' or Noël Carroll's “"neoWittgensteinian" theory of intentions, whereby intention is "a purpose, manifest in the artwork",

34 Ethan Haimo, 'Atonality, Analysis, and the Intentional Fallacy', Music Theory Spectrum, 18 (1996), 167-99 at 178 , seems to assume that intentions need to be conscious. For arguments against this assumption, refer to Stanley Cavell, 'A Matter of Meaning It', in Must We Mean What We Say? (Cambridge, 2002), 234-5; Paisley Livingston, Art and Intention: A Philosophical Study (Oxford, 2005), pp. x, 42-3.

35 Livingston, Art and Intention, 7. See also Alfred R. Mele, 'Deciding to Act', Philosophical Studies, 100 (2000), 81-108 at 100 . 
not logically independent of the work.' 36 Such proposals seem to respond to the observation that not all actions are preceded by a conscious, prior intention. But equating intentions with actions prevents us from distinguishing between skilful activities and fortuitous accidents. Furthermore, if intentions were immanent to the product the artist produces (text, sound-structure, performance, recording), it would be incoherent to speak, as we often do, of that product failing to realize the artists' intentions.

Livingston contends that '[i]ntentions are prior and future-directed,' but notes that this stipulation 'does not mean that they cannot function to sustain, adjust, and guide an action once it is in progress'. Intentions need not be the product of deliberation nor need they be entertained consciously. Thus, a commitment to intentionalism does not entail regarding art-making as an entirely rational, highly controlled endeavour. '[I]ntentions can be formed 'at the speed of thought",, and are subject to revision based on changing circumstances or the artist's whims.37

\section{Hypothetical Intentionalism}

Turning to the role intentions play in the interpretation of art, anti-intentionalists believe that art is autonomous from its creators and the contexts in which they were working. Thus, they reject the relevance of intentions to some or all interpretive questions. Proponents of hypothetical intentionalism begin from a similar premise. However, observing that art-making is an intentional endeavour, they frame their inquiries in terms of the actions and intentions of an agent. The difference between their approach and that of actual intentionalists is that this agent is not the work's actual maker but, rather, an author-construct, created by the reader or listener

36 John R. Searle, Intentionality: An Essay in the Philosophy of Mind (Cambridge, 1983), chap. 3; quotation from Livingston, Art and Intention, 143; embedded quotation from Noël Carroll, 'Art, Intention, and Conversation', in Gary Iseminger (ed.), Intention and Interpretation (Philadelphia, PA, 2010), 97-131 at 101. Kindred views include G. E. M. Anscombe, Intention (Oxford, 1957); Colin Lyas, 'Wittgensteinian Intentions', in Gary Iseminger (ed.), Intention and Interpretation (Philadelphia, PA, 2010), 132-51.

37 Livingston, Art and Intention, 10. 
through his or her engagement with the text, sound-structure, or performance. The most common term for the resulting entity is the 'implied author' but various alternatives have been proposed, including 'fictional', 'postulated', and 'second' authors.

One of the reasons for the emergence of these various monikers is divergent opinions about the degree to which one's author-construct ought to accord with facts about the work's actual author(s). Philosopher Alexander Nehamas's 'postulated author' and music theorist Seth Monahan's 'fictional composer' may be quite unlike the work's actual makers. ${ }_{38}$ Observing the contradictory portraits of Beethoven that have emerged in analyses of a single work, Monahan declares that none are "verifiably more authentic or "correct" than the others.' Fictional composers need not be 'plausible reconstructions of the historical artist'. Although he acknowledges the tendency to 'align one's fictional composer (ideologically, epistemically, psychobiographically) with the historical one', he suggests that this impulse 'should be taken as a self-imposed hermeneutic constraint and nothing more.'39

When literary critic Wayne C. Booth introduced the concept of the 'implied author' in The Rhetoric of Fiction (1961), he surely envisioned a greater degree of correspondence between implied and real author.40 Although the phrase 'implied composer' does not appear in Edward T. Cone's The Composer's Voice (1974), Cone has subsequently acknowledged that his concept of the 'complete' or 'implicit musical persona' is 'something very like Booth's implied author'.41 Like Booth, Cone stresses the importance of distinguishing between the historical author and the

38 Alexander Nehamas, 'The Postulated Author: Critical Monism as a Regulative Ideal', Critical Inquiry, 8 (1981), 131-49; Seth Monahan, 'Action and Agency Revisited', Journal of Music Theory, 57 (2013), 321-71 at 329-32. Monahan cites Nehamas. A similar position has been put forth by Gregory Currie, 'Interpretation and Objectivity', Mind, 102 (1993), 413-28 at 418.

39 Monahan, 'Action and Agency Revisited', 330, 331, 331n20.

40 Wayne C. Booth, The Rhetoric of Fiction, 2nd ed. (Chicago, IL, 1983), 70-1.

41 In Edward T. Cone, The Composer's Voice (Berkeley, CA, 1974), 2n4, Cone acknowledges being 'greatly indebted' to The Rhetoric of Fiction; quotation from Cone's contribution to 'Edward T. Cone's The Composer's Voice: Elaborations and Departures’, College Music Symposium, 29 (1989), 1-80 at 77. 
image of the author that may be gleaned from engaging with his or her works.42 Nevertheless, the personae that emerge from Cone's interpretive activities are congruent with facts about the historical persons known as Franz Schubert, Ludwig van Beethoven, and so on. In the intervening years, the concept of the 'implied composer' has become commonplace in writings by music semioticians. 43

Philosopher Jerrold Levinson has put forth an even more historically situated version of hypothetical intentionalism. Unlike the previous scholars, Levinson contends that the interpreter's task is not 'to hypothesize an author, and subsequently what such a hypothetical agent might have intended, but rather to hypothesize, in a fully contextually informed manner, about the actual author'.44 From this quotation, Levinson's version of hypothetical intentionalism may seem strikingly similar to real author intentionalism. Where these stances diverge is in the kind of evidence that rightly figures in one's hypotheses. Due to Levinson's commitment to the autonomy of art, he stipulates that one's interpretation may only be based on publically available information. Information contained within private sources like letters and diaries is inadmissible, even if the author intended some readers or listeners to be in possession of such knowledge. Also off-limits for Levinson are artists' statements about their semantic intentions, even if these statements were made in a public context, such as a newspaper article or television interview. 45

42 Cone, Composer's Voice, 2, 57, 84-5.

43 For example, Eero Terasti, Signs of Music: A Guide to Musical Semiotics (Berlin, 2002), 73-6.

44 Jerrold Levinson, 'Defending Hypothetical Intentionalism', British Journal of Aesthetics, 52 (2010), 139-50 at 140-1. Levinson's original statement of his position may be found in 'Intention and Interpretation in Literature', in The Pleasures of Aesthetics: Philosophical Essays (Ithaca, NY, 1996), 175-213. William E. Tolhurst, 'On What a Text Is and How It Means', British Journal of Aesthetics, 19 (1979), 3-14, outlines a similar position. 45 Levinson, 'Intention and Interpretation', 178n11, 206-7; Jerrold Levinson, 'Hypothetical Intentionalism: Statement, Objections, Replies', in Contemplating Art: Essays in Aesthetics (Oxford, 2006), 302-15 at 306. 
In many, if not most, cases the information contained within such sources is not likely to contradict an interpretation based solely on the finished work's features and publically available information about its author and context of creation. Thus, Levinson would reach similar conclusions to real author intentionalists of the moderate variety (to be defined in the following section) in most cases. One instance where knowledge of artists' private lives may open up new interpretive possibilities is in the case of gay artists who, under threat of social persecution, even imprisonment, were required to maintain a heterosexual (or at least not explicitly queer) public persona. Although they could not represent queer relationships or themes explicitly in their works, some nevertheless succeeded in doing so implicitly. Benjamin Britten and Myfanwy Piper's television opera Owen Wingrave (1971) is one such example.

According to the work's explicit content, the titular character is marginalized because he is a pacifist in a military family. Britten and Piper's musical and textual strategies of marshalling sympathy for Owen and representing his family as bellicose villains, incapable of critical thought, render the explicit message of the work one of pacifism. Implicitly, however, Owen's predicament is also expressive of a queer subject position, and thus the work may be interpreted as conveying a queer-affirmative message as well. This latter possibility is not open to the hypothetical intentionalist, however.

Levinson has clarified that 'public information' ought to be understood along the lines of 'what the author appears to have wanted his or her readers to know about the circumstances of a work's creation, beyond what is implicit in the author's previous work and the author's public identity.' 46 Even after Britain's decriminalization of homosexual acts in 1967, Britten maintained that his relationship with the tenor Peter Pears was one of professional colleagues and platonic

46 Levinson, 'Hypothetical Intentionalism', 310n15. 
friends. He did not appear to have wanted the public at large to bring his sexual identity to bear on the interpretation of his works. Since the queer dimensions of Owen Wingrave are not explicit, they are not fully determined by the work's libretto and score. Yet, the evidence that would ground such an interpretation is confined to those 'private' sources which the hypothetical intentionalist proposes drawing a veil of ignorance to obscure.

The twenty-first-century musicologist, with knowledge of the contents of Britten's letters to Pears and other male lovers, brings a different image of the composer to bear on the interpretation of Owen Wingrave.47 In light of Britten's sexual identity and awareness of gay culture, various curious features of the libretto and score take on a new significance. Textual clues include Owen's aunt's ominous declaration 'he shall be straightened out at Paramore', the various times Owen's manliness is called into question, and Owen's attempt to demonstrate it by letting his girlfriend Kate lock him in a closet. There are also queer dimensions to Britten's music. When Owen is summoned to his grandfather's office to justify himself, we only hear snippets of the elder Wingrave's outraged responses, not what is prompting them. Owen's utterances are represented by an off-stage horn. In a possible allusion to the 'love that dare not speak its name', we never discover the precise reasons for Owen's disinheritance.48 Finally, in Owen's paean to peace in Act II, Britten evokes the timbres and textures of Balinese gamelan

47 Many of their letters were published in Mervyn Cooke, Donald Mitchell, and Philip Reed (eds.), Letters from a Life: The Selected Letters of Benjamin Britten, 1913-1976, 6 vols. (Woodbridge, 1991-2012). Their complete correspondence appears in Vicki P. Stroeher, Nicholas Clark, and Jude Brimmer (eds.), My Beloved Man: The Letters of Benjamin Britten and Peter Pears (Martlesham, 2016).

48 The quotation is from the poem 'Two Loves' (1894) by Lord Alfred Douglas, mentioned in Oscar Wilde's 1895 trial for gross indecency. For a more extended queer interpretation of the opera, refer to Stephen McClatchie, 'Benjamin Britten, Owen Wingrave and the Politics of the Closet; or, "He Shall Be Straightened out at Paramore", Cambridge Opera Journal, 8 (1996), 59-75. 
music, a topic with overtly erotic associations in Britten's other works, such as The Turn of the Screw (1954).49

Based on a more complete picture of the composer and the influences on his works, Britten scholars today regard Owen Wingrave not only as a plea for peace but also as a plea for acceptance of queer persons. The divergence between the meaning a hypothetical intentionalist is apt to ascribe to Owen Wingrave and those currently accepted by Britten scholars suggests that hypothetical intentionalism is a poor fit with current interpretive practices in musicology.50 Indeed, hypothetical intentionalism is ill-equipped to explain many commonplace musicological activities, such as studying composers' sketches, notebooks, letters, and diaries, or conducting and transcribing interviews. Such sources provide evidence of the historical author's actions and intentions, not those of the implied author. If all composer-related inquiries are to be directed towards the latter entity, it is unclear what relevance the former's documents and statements would have. Although Levinson seems to respond to this concern by stipulating that our hypotheses ought to be directed towards the actual author, he nevertheless excludes much of the evidence contained within the aforementioned sources. The divergence between the real Benjamin Britten and one based solely on the sources permitted to the hypothetical intentionalist suggests that Levinson is not hypothesizing about the actual composer but an author-construct, if one with more similarity to the historical composer than those invoked by Nehamas or Monahan.51

${ }_{49}$ Philip Brett, 'Eros and Orientalism in Britten's Operas', in George E. Haggerty (ed.), Music and Sexuality in Britten: Selected Essays (Berkeley, CA, 2006), 129-53.

50 Karol Berger, 'The Text and Its Author', Music als Text, 1 (1998), 58-60 at 60, also observes a conflict between the concept of the implied author and historically oriented scholarship.

51 Robert Stecker and Stephen Davies, 'The Hypothetical Intentionalist's Dilemma: A Reply to Levinson', British Journal of Aesthetics, 50 (2010), 307-12 at 308, make a similar point. 


\section{Moderate Actual Intentionalism}

In contrast to hypothetical intentionalists, actual intentionalists place no limits on the kinds of evidence that may factor into art interpretation. That is because they reject the premise motivating both anti- and hypothetical intentionalism: the autonomy of art. For the actual intentionalist, artworks are not merely the products the artist produces but more akin to processes, actions, or utterances.52 As such, they are inseparable from the myriad artistic, social, and political influences on their creation. This view of the ontology of music is at odds with the New Musicologist's belief that musical works are scores or sound-structures that the historian must place in the appropriate context. However, it is congruent with the premises of New Historicism as well as actor-network theory. Benjamin Piekut observes that Latour's mantra 'follow the actors' 'differs greatly from the robotic injunction to "add context" to the object of historical study, for [actor-network theory] rejects the separation of text from context ab initio'.53

For the actual intentionalist, interpreting a work (as opposed to merely its text or soundstructure) involves investigating its process of creation, including the intentions of any agents involved in that process. This line of inquiry does not require mind-reading abilities or even explicit statements of authorial intent. Even when such statements are available, inquiry into the artist's intentions should not begin and end with their examination. There are various reasons why they may lead one astray. The artist may have uttered those statements with the intent to deceive. Even if artists intend to be truthful, they may misremember or be under some delusion about the actual intentions that motivated their actions. If such statements were made during the

52 For example, Paisley Livingston, 'On Cinematic Genius: Ontology and Appreciation', Royal Institute of Philosophy Supplement, 71 (2012), 85-104 at 92, argues that artworks are both products and processes. For a more fully elaborated argument in favour of a process-oriented ontology of art, refer to David Davies, Art as Performance (Malden, MA, 2004). It should be noted that Davies is not an intentionalist.

53 Benjamin Piekut, Experimentalism Otherwise: The New York Avant-Garde and Its Limits (Berkeley, CA, 2011), 8. 
artistic process, the may reflect plans that were subsequently abandoned. Even if the artists did act on their stated intentions, they may have been unsuccessful in realizing them. For these reasons, one ought to question the absolute intentionalist's equation of an artwork's content with its authors' intentions.54 Thankfully, absolute intentionalism is not the only form of intentionalism currently on offer.

One of the upshots of the battering intentionalism took in the middle portion of the twentieth century is that it spurred analytic philosophers to come up with more sophisticated accounts. The most robust of these is moderate actual intentionalism. Its chief advocatesPaisley Livingston, Robert Stecker, and Noël Carroll — each spell out its precepts in subtly different terms.55 What unites them is a belief that, if one is interested in historically sensitive understandings of art, interpretation involves figuring out what the artists were attempting to do and whether or not they were successful. The resulting methodology bears considerable congruence with those of historically minded musicologists: investigating how the work was produced (by consulting sketches, drafts, notes, letters, and the like) and the various influences on its production, both human and non-human (other artists or artworks; the performers, instruments, or venue for which it was written; technology employed in its composition or performance; censors, commissioning bodies, arts organizations; art-critical, scholarly,

54 Defences of absolute intentionalism include E. D. Hirsch, Validity in Interpretation (New Haven, CT, 1967); William Irwin, Intentionalist Interpretation: A Philosophical Explanation and Defense (Westport, CT, 1999); William Irwin, 'Authorial Declaration and Extreme Actual Intentionalism: Is Dumbledore Gay?', Journal of Aesthetics and Art Criticism, 73 (2015), 141-7; P. D. Juhl, Interpretation: An Essay in the Philosophy of Literary Criticism (Princeton, NJ, 1980); Steven Knapp and Walter Benn Michaels, 'Against Theory', Critical Inquiry, 8 (1982), 723-42; Steven Knapp and Walter Benn Michaels, 'Against Theory 2: Hermeneutics and Deconstruction', Critical Inquiry, 14 (1987), 49-68.

55 Livingston, Art and Intention, 142-3; Robert Stecker, Interpretation and Construction: Art, Speech, and the Law (Malden, MA, 2003), 42; Robert Stecker, 'Moderate Actual Intentionalism Defended', Journal of Aesthetics and Art Criticism, 64 (2006), 429-38 at 429; Noël Carroll, 'Art Interpretation', British Journal of Aesthetics, 51 (2011), 117-35 at 119-21; Noël Carroll, 'Criticism and Interpretation', Sztuka i filozofia, 42 (2013), 7-20 at 14. 
philosophical, or other texts; social or political events; events in the artists' personal or professional life).

To illustrate how moderate intentionalism works in practice, let us imagine that we are at the opera seeing Cosi fan tutte, directed by Atom Egoyan (Canadian Opera Company, 2014). For the purposes of this example, let's assume that we are well acquainted with Mozart and Da Ponte's work. Rather than puzzling over the nature of their artistic achievement, our interpretive dilemma concerns the features of the performance we are watching. Specifically, we are at a loss about how to interpret some features of the staging. Although it was generated through a collaborative effort, Egoyan has served to direct and coordinate the efforts of his team towards realizing his interpretation of Mozart and Da Ponte's work. As such, I will be focusing on Egoyan's intentions. Inquiry into the director's or performers' intentions is just as pertinent to appreciating their performance as the composer's intentions are in appreciating the work being performed. Thus, the fact that we're focusing on a performance rather than the work being performed does not make a difference to the relevance of authorial intentions.

Dutiful spectators that we are, we use the time remaining before curtain up to read the Director's Notes. There we discover that Egoyan has several 'surprises' in store for us. The first is that he is taking the opera's subtitle 'La scuola degli amanti' (the school for lovers) literally, setting the opera in a prep school. More intriguing is his decision to modify the epistemic position of the sisters Fiordiligi and Dorabella.56 In a performance that adheres closely to the libretto, the sisters' boyfriends, Ferrando and Guglielmo, make a wager with their friend Alfonso concerning their lovers' fidelity. The boyfriends pretend to leave for war but instead disguise

56 Atom Egoyan, 'Director's Notes', program to a performance of Così fan tutte, Canadian Opera Company (2014), 3. 
themselves as Albanians and attempt to woo the sisters. The sisters only learn of the men's wager after they have committed themselves to their 'new lovers'.

Wrestling with some of the more preposterous elements of the plot—such as turbans and fake moustaches preventing the sisters from recognizing their lovers - and the misogyny of numbers like 'Donne mie la fate a tanti', Egoyan decided to have the women be cognizant of the men's wager from the beginning.57 Additionally, he 'was curious to explore what might happen to the dynamics of the opera if there were a parallel wager with the two women. While we can't know the specific nature of this wager, we gather it concerns marriage.' 58

Attempting to interpret Egoyan's production in light of his remarks only leads to confusion. Nothing about the performance suggests that we ought to regard the sisters as aware of the wager or as undertaking a counter-wager. Although they are on stage for the men's wager, they are asleep not eavesdropping. When the men announce that they have been sent to the front lines, the women appear to be genuinely distraught. During 'Smanie implacabili', Dorabella performs no playful winks to her sister, or to the audience, to let us know that it's all an act. And since Egoyan has made no alterations to Da Ponte's sung text, nor has he attempted to convey his alterations of the plot via wilfully inaccurate surtitles à la Peter Sellars, he was unable to establish a counter-wager between the sisters. 59 How is the moderate intentionalist to interpret the women's epistemic position in Egoyan's production?

According to moderate actual intentionalism, authorial intentions only determine meaning in cases where they are successfully realized in the product the artist produced; in this

57 Egoyan mentions the issues of credibility and misogyny in the following promotional video for the production: www.youtube.com/watch?v=QWRoXiLeR0Q.

58 Egoyan, 'Director's Notes', 3.

59 See, for example, Peter Sellars, dir., Cosi fan tutte, (Decca, 2005), DVD. For a production that was successful in communicating that the women were 'in' on the ruse, see Ursel Herrmann and Karl-Ernst Herrmann, dir., Cosi fan tutte, Salzburg Festival, 2006 (Decca, 2006), DVD. 
case, the performance we were watching. For Livingston, success is determined by spectators employing the means just described: assessing whether the intention and the features of the artistic product 'mesh'. Meshing entails not only a degree of consistency between the intention and the work's perceptual features, 'but also carries the implication of a stronger condition involving relevance and integration: if there is a sense in which an extraneous hypothesis is consistent with data, but bears no meaningful, integrative relation with them, we would say that the two do not mesh.' Livingston suggests that a 'symptom or epistemic indication ... is whether any interpreters who are unaware of the intention as expressed separately (in an interview or diary, for example) would be even moderately likely, given knowledge of the text or structure and relevant art-historical contextual factors, to understand the story along the lines indicated by the intention in question.' However, since 'some highly unlikely intentions in fact mesh quite well with a text once they become known', he notes that this is 'not a logical criterion or decisive determination'.60

Egoyan's stated intention to establish a counter-wager between the sisters was incongruent with the production he and his team created. As a spectator who read the Director's Notes and saw the promotional videos prior to attending the opera, I found Egoyan's remarks distracting to my efforts to understand the performance. Many critics reported similar experiences of befuddlement or, for those who did not read the program or watch the promotional videos, ignorance of any intended alterations of the plot.61 There are at least two

${ }_{60}$ Livingston, Art and Intention, 199-200. Stecker and Carroll define the 'success condition' in somewhat different terms. According to Stecker, 'Moderate Actual Intentionalism', 429, 'an utterer successfully intends a meaning X just in case the utterer intends $X$, the utterer intends that the audience will grasp this in virtue of the conventional meaning of the utterer's words or an extension of the meaning permitted by those conventions, and the first intention is graspable in virtue of those conventions or permitted extensions of them'. For Carroll, 'Art Interpretation', 119, the intention must merely be 'consistent with the way the work is.' ${ }_{61}$ John Gilks, 'A School for Lovers', 19 Jan. 2014, Opera Ramblings blog, operaramblings.wordpress.com/2014/01/19/a-school-for-lovers/; Christopher Hoile, Review of Atom Egoyan's Così 
possible ways of explaining the inconsistency of Egoyan's statements with the resulting production. He may have been unsuccessful at realizing his intentions. Alternatively, his Director's Notes may represent an earlier, abandoned plan for his production.

Even though Egoyan's stated intentions do not determine what spectators ought to imagine about the sisters and their plans, they still have bearing on the appreciation of Egoyan's production. They may testify to a change in Egoyan's approach. Or, if he maintained his intention that the women be cognizant of the wager, he may have miscalculated what would be required to successfully realize this intention, namely, more significant departures from the libretto and stage directions. If so, his production would display less skill than one possessing the same observable features but where the results and the intentions that produced them were congruent. Another possibility is that Egoyan's intentions to depart from the performing directions were overruled by the management of the Canadian Opera Company, in which case, they would be to blame for the incoherence.

Due to the presence of a success condition, moderate intentionalism is immune to the most serious problem facing absolute intentionalism: the possibility that intentions, even those acted upon, can fail. A variety of other concerns have been raised against real author intentionalism. I will respond to the most serious of these in turn.

Of particular concern to Taruskin as well as to feminist musicology is that real-author intentionalism is yoked to Great-Man historiography. Given that absolute forms of intentionalism have abetted attempts to tell history in terms of the accomplishments of, predominantly, great

fan tutte, Opera News, 78 (2014), operanews.com/Opera_News_Magazine/2014/4/Reviews/TORONTO_Così_Fan_Tutte.html; Arthur Kaptainis, 'The Canadian Opera Company Mounts Clash of Concepts with Cosi fan tutte', National Post, 20 Jan. 2014 , news.nationalpost.com/arts/opera-review-the-canadian-opera-company-mounts-clash-of-concepts-with-cosi-fantutte. 
white men, this concern is a legitimate one. However, moderate intentionalism is less amenable to such historiographic projects for a couple of reasons. First, it recognizes that the creation of art is enmeshed in social and political contexts of various sorts. The same cannot be said of either Wimsatt and Beardsley's New-Critical programme or of Roland Barthes's poststructuralist one, given the minimal or even optional role such historical facts play in these critics' approaches to interpretation.

Second, real author intentionalism does not commit one to regarding authorship as an individual activity or that single authorship is more likely to result in works that are artistically superior to those created by multiple authors. Livingston has refuted the idea, promulgated by literary theorist Seymour Chatman, among others, that the practice of art criticism would benefit from setting aside the messy facts about how collaborative artworks were created and posting a single, implied author.62 One of the reasons for my focus on multi-authored works is to show that intentionalism is able to contend with the 'messiness' of music-making in the real world.

Moderate intentionalism's concern with actual processes of creation, as opposed to relying on a priori assumptions about who did what, can be used to uncover the work of artists whose contributions have gone unrecognized because of their gender, race, social class, or other marginal position. In opera scholarship, for instance, there is a tendency to attribute to the composer much of the work actually conducted by librettists and singers, but to turn to such collaborators when critiquing flaws, such as Owen Wingrave's lopsided representation of the two sides of its central conflict concerning the ethics of war.

62 Seymour Chatman, Coming to Terms: The Rhetoric of Narrative in Fiction and Film (Ithaca, NY, 1990), 90-7. Livingston devotes a large portion of his chapter on authorship to collective examples. Art and Intention, 75-89. See also his Cinema, Philosophy, Bergman: On Film as Philosophy (Oxford, 2009), chap. 3. 
Like several other critics, I regard this bias towards Owen and his pacifist stance to be a flaw from both moral and artistic perspectives. When it comes to placing blame, early critics were quick to point the finger at Britten's librettist, Myfanwy Piper.63 An examination of the actual process of creation makes it clear that this bias was of concern for Piper and that she took steps to ameliorate it by rounding out Owen's opponents, particularly his girlfriend Kate. Piper was responsible for inserting a brief lyrical moment of reminiscence for the couple during their final conversation.64 Sadly, Britten largely ignored Piper's advice and, furthermore, proposed insertions that counteracted her efforts at damage control; for instance, requesting a scene in which Kate flirts with Owen's friend Lechmere in front of Owen and his family.65 Taking an interest in whose intentions actually determined the work's features has the potential to uncover many more misconceptions, not only about the working relationships between composers and librettists but also the contributions of the performers for whom the work was written.

Considering the tendency to view all of Britten's works as attempts to work through his homosexual and paedophilic desires, one might also harbour the concern that intentionalism encourages reductive biographical criticism. Since a work includes all aspects of its generative process, an artist's personal life and emotional and psychological states leading up to and during the creation of the work are at least potentially germane to understanding why it possesses the features it does. However, that should not lead one to approach artworks as if they were mere products of the 'writing cure'. It is clear that Britten's sexuality and pacifist convictions were factors that drew him to characters like Owen Wingrave and Peter Grimes, and influenced how

63 For example, Winton Dean, 'Music in London', Musical Times, 114 (1973), 719-26 at 719.

64 Myfanwy Piper, 'Writing for Britten', in David Herbert (ed.), The Operas of Benjamin Britten (New York, 1979), 8-21 at 14-15; Frances Spalding, 'Dramatic Invention in Myfanwy Piper's Libretto for Owen Wingrave', in Lucy Walker (ed.), Benjamin Britten: New Perspectives on His Life and Work (Woodbridge, 2009), 86-96 at 90. 65 Myfanwy Piper, interview by John Amis in 1970 for the BBC's 'Music Now', in Colin Graham, dir., Owen Wingrave (Decca, 2009), DVD. 
he approached their operatic adaptation. But if, as Claire Seymour has suggested, Peter Grimes is not a "public manifesto but rather ... a private letter in which Britten musically re-examined his inner anxieties' about his sexuality and relationships with boys, it would be difficult to explain why anyone else would find value in the work.66

Britten's pack-rat tendencies have ensured that scholars possess extensive documentation of his intentions and working processes, but for many works, especially from the more distant past, the finished product as well as general facts about its historical context may be all we have on which to base our interpretation. The observation that there are limits to what knowledge may be attained should not cause us to abandon the search for such knowledge. As Livingston notes, using the unattainability of knowledge as evidence for its irrelevance or undesirability 'looks like a case of "sour grapes".' 67

Evidence about the historical artist's character and beliefs can conflict the impression one receives of the author from reading his or her works. A canonical example is Thomas Mann's novella Der Tod in Venedig (1912). A reader approaching this work without any knowledge of Mann's life and attitudes is likely to assume that he was a highly judgmental individual who felt no sympathy for his protagonist, Gustav von Aschenbach. In reality, Mann based much of the story on personal experience and had considerable sympathy for Aschenbach's struggles with homosexual and paedophilic desire. 68

Wayne Booth invented the concept of the implied author for such situations. 'Just as one's personal letters imply different versions of oneself, depending on the differing

${ }_{66}$ Claire Seymour, The Operas of Benjamin Britten: Expression and Evasion (Woodbridge, 2004$), 73$. 67 Livingston, Art and Intention, 169.

68 Mann reveals his own opinions on homosexual desire, and other matters, in a letter to Carl Maria Weber, 4 July 1920. Letters of Thomas Mann, 1889-1955, trans. Richard Winston and Clara Winston (New York, 1971), 102-6. For a more thorough discussion of this case, see Dorrit Cohn, The Distinction of Fiction (Baltimore, MD, 1999), chap. 8. Cohn uses the concept of the 'second author' to describe the image of Mann project by the text. 
relationships with each correspondent and the purpose of each letter, so the writer sets himself out with a different air depending on the needs of particular works.' 69 Booth undermines the necessity of his new theoretical apparatus by pointing to everyday communicative situations. Pace Booth, understanding a letter does not involve making inferences about what the implied author of the letter intended to communicate; it involves making inferences about the intentions of the actual person who authored the message.

In everyday life, we have no difficulty understanding how our manner of communication, and thus the image of ourselves that may be gleaned from our correspondence, can change depending on the addressee, context, and purpose of the message. We accept that some of our utterances reveal our personalities and convictions more fully and faithfully than others without having to invoke entities like the implied author.70 I suggest that a similar approach may be taken towards Der Tod in Venedig: Mann told the story according to a point of view he did not himself hold. To understand the possible motivations for such a decision, I find philosopher Gregory Currie's theory of irony helpful. Currie argues that irony is the adoption of a pretended point of view, typically for the purpose of pointing out its deficiencies.71 I suggest that Mann's aim in pretending to be unsympathetic to his protagonist was to point out the flaws in such a conservative worldview and to arouse sympathy for Aschenbach and his plight.

Finally, given that the liberation of the reader was the primary motivation for Barthes's dethroning of the author, one may be concerned that a commitment to real author intentionalism

${ }_{69}$ Booth, Rhetoric of Fiction, 71.

70 Marie-Laure Ryan, 'Meaning, Intent, and the Implied Author', Style, 45 (2011), 29-47 at 42, makes a similar point. Other recent critiques of the implied author in literary theory include David Herman, 'Narrative Theory and the Intentional Stance', Partial Answers, 6 (2008), 233-60 at 241-4; Herman's contribution to 'Authors, Narrators, Narration', in David Herman, James Phelan, Peter Rabinowitz, Brian Richardson, and Robyn Warhol (eds.), Narrative Theory: Core Concepts and Critical Debates (Columbus, OH, 2012), 29-56 at 44-50; Tom Kindt and Hans-Harald Müller, 'Six Ways Not to Save the Implied Author', Style, 45 (2011), 67-79.

${ }_{71}$ Gregory Currie, Narrators and Narrators: A Philosophy of Stories (Oxford, 2010), chap. 8. 
would stifle the creativity of the interpreter. 72 The range of interpretations open to the real author intentionalist is, indeed, more restrictive than those available to the value maximizer or the hypothetical intentionalist. Real author intentionalism may lead one to interpretations that render the work less artistically successful or personally satisfying than others that may be coherently ascribed to the text, sound-structure, or performance. This is where moderate actual intentionalism parts ways from hypothetical intentionalism and value maximization. In so far as the author's intentions are congruent with the finished work, taken in light of the relevant conventions, the moderate actual intentionalist must privilege the intended interpretation over others than may render the work more successful or appealing.73 With respect to Brandenburg Concerto no. 5, the moderate intentionalist ought to prefer Marissen's interpretation over McClary’s, even if one finds McClary's more interesting.

That is not to say that there is no place for McClary's interpretation, however. If one's aim is to show the relevance of Baroque music to a contemporary, American audience, there is no better place to look than the work of Susan McClary. Art criticism admits of a plurality of aims, not all of which are well-served by a commitment to intentionalism. 74 However, as evidenced by the New-Historical impulses in current musicology, many members of the discipline are interested in understanding musical works and performances as creations by historical persons. I argue that moderate actual intentionalism is the theory that is most congruent with the practices of such critics.

72 Roland Barthes, 'The Death of the Author', in Stephen Heath (ed. and trans.), Image - Music - Text (New York, 1977), $142-8$ at 148 .

73 S. Davies, 'Authors' Intentions', 239-40.

74 Livingston, Art and Intention, 142; Stecker, Interpretation and Construction, 35, both make this point. 


\section{The Inescapability of Intentions}

Even if one's aims are better served by value maximization or hypothetical intentionalism, there are some interpretative questions that demand inquiry into the actual artist's intentions. One such question is whether a work is finished or incomplete. In Joy Calico's study of Brecht's engagement with opera, she examines both his finished operas and numerous opera-fragments, drawing on Livingston's concept of 'genetic completion' to distinguish between the two. 75 Livingston defines two different senses in which we may speak of a work as being complete. The first, aesthetic completion, is the definition a formalist is likely to put forth: 'a work can be said to be complete or finished in the sense that the item in question, when appreciated in light of the relevant artistic categories, manifests certain features that are positively valued within those categories, such as coherence, resolution, the right sort of dénouement, the possession of all the essential or characteristic elements of the genre or form, and so on.'

The problem with relying solely on aesthetic completion is that there are works that are considered to be complete that lack this sort of completion. As an example, Livingston provides the imitation Roman temple at the Villa Albani in Rome, which was deliberately constructed to look like a fragment of 'some larger, missing whole.' To describe the sense in which such a work is complete, Livingston introduces the concept of genetic completion, which occurs when the artist arrives at a 'retrospective judgment that this work and its creation are ... complete, at least as far as the artist's own contributions are concerned.' 76 Yet, for artists operating under the belief that artistic creation is 'necessarily incomplete' or 'always already endless', the foregoing definition would seem to suggest that such artists never complete any of their works. 77 More

75 Joy H. Calico, Brecht at the Opera (Berkeley, CA, 2008), 174-5n55.

76 Livingston, Art and Intention, 54, 56.

77 Kelly Trogdon and Paisley Livingston, 'Artwork Completion: A Response to Gover', Journal of Aesthetics and Art Criticism, 73 (2015), 460-2 at 460. 
recently, Livingston, in collaboration with Kelly Trogdon, couch artistic completion in terms of the artist acquiring a 'completion disposition with respect to her work - a disposition to refrain from making significant changes to the work'.78

More controversially, Calico takes an intentionalist approach to determining which of Brecht's works are properly understood as operas. 'Given that the refunctioning of the genre was part of his agenda, ascertaining genre by generally accepted characteristics is ineffectual', she observes. Calico consider as operas 'those texts in Brecht's oeuvre that he designated as such', citing precedent in work by Livingston and Sherri Irvin.79 In analytic aesthetics, there is an uncharacteristic convergence on the idea that the real author's intentions have a role to play in determining a work's genre or 'category of art', even among philosophers like Irvin who do not endorse intentionalism as a general approach to interpretation.80 Although Levinson rejects the proposition that the author's semantic intentions have a role to play in determining a work's meaning, he argues that the author's categorical intentions-for example, that the text be regarded as a poem as opposed to a short story or a grocery list—'virtually cannot fail—so long as the text in question at least allows of being taken, among other things, as a poem.' 81

In music scholarship, by contrast, Calico's position is an outlier. A consensus has been reached about the limitations of defining genres solely in terms of sets of characteristic features. Nevertheless, current theories of genre place more emphasis on listener response than authorial intent. In Eric Drott's discussion of genre in post-1945 art music, composers' actions and intentions contribute to genre definition, but they are seemingly no more privileged an 'actor' in

78 Kelly Trogdon and Paisley Livingston, 'The Complete Work', Journal of Aesthetics and Art Criticism, 72 (2014), $225-33$ at 225.

79 Calico, Brecht at the Opera, 4. Calico cites Livingston, Art and Intention, 55; Sherri Irvin, 'The Artist's Sanction in Contemporary Art', Journal of Aesthetics and Art Criticism, 63 (2005), 315-26 at 315-16.

80 The quotation refers to a classic essay in analytic aesthetics, Kendal L. Walton, 'Categories of Art', Philosophical Review, 79 (1970), 334-67, in which Walton defends an intentionalist approach to categorization.

81 Levinson, 'Intention and Interpretation', 188. 
this process than 'performers, publishers, audiences, critics, music industry personnel, arts administrators, and music scholars'.82 Even though David Brackett describes his recent study of genre in popular music as 'historicist', even 'genealogical' (as opposed to 'presentist' or 'retroactive'), he nevertheless proposes '[r]emoving the idea of authorial intention from an understanding of genre'. Yet, as he acknowledges, his 'discussion of an artist's adjustments to an imagined audience may appear to re-import the notion of artistic intention through a back door.' 83

Musicologists' hesitance to award authors sole authority in this matter is justified by cases like Montréal-based composer Luna Pearl Woolf’s Mélange à trois (2014), a 'voiceless opera' for violin, cello, and percussion. When I interviewed Woolf and asked about her reasons for describing her work in this way, she pointed to the one-to-one mapping of instruments to fictional characters, with the sounds emitted by the instruments representing the characters' 'voices'. Additionally, its love-triangle plot also evokes the stock scenarios of nineteenth-century opera. But given the work's lack of a standard feature of opera — singing — 'instrumental theatre' would seem to be a more appropriate category in which to appreciate it. 84 Bringing the genre expectations of opera to Mélange à trois is likely to lead to confusion, even disappointment, by the lack of singing, whereas approaching it as a work of music theatre, inspired by various features of opera, would likely be more rewarding. According to moderate actual intentionalism, even an author's categorical intentions can fail.85 But even if Woolf's categorization does not

82 Eric Drott, 'The End(s) of Genre', Journal of Music Theory, 57 (2013), 1-45 at 9.

83 David Brackett, Categorizing Sound: Genre and Twentieth-Century Popular Music (Berkeley, CA, 2016), 4-5, 14.

84 Here I use 'standard' in Walton's sense: 'A feature of a work of art is standard with respect to a (perceptually distinguishable) category just in case it is among those in virtue of which works in that category belong to that category - that is, just in case the lack of that feature would disqualify, or tend to disqualify, a work from that category.' Walton, 'Categories of Art', 339.

85 Livingston, Art and Intention, 162. 
determine the work's genre, it remains relevant to interpretation as it gestures towards the influence of opera on the composition of the work.

Another interpretive question generally regarded to require recourse to authorial intentions is whether the work contains quotations of other works or instances of allusion, parody, or irony.86 The limits of a purely formalist approach to such topics may be illustrated by the debate concerning whether Prokofiev's Symphony-Concerto, Op. 125 contains a parody or quotation of Isaak Lyuban or Vladimir Zakharov.87 As Taruskin observes, the resemblance between a passage of the finale to some songs by these composers is enough to render it a plausible instance of borrowing. Furthermore, its "“wrong” ... harmonies' and 'impossibly banal bass lines' suggests parodic intent. 88 Yet, to determine whether it is a parody of Lyuban or Zakharov involves more than mere comparison of the sound-structures of these compositions. A purely formalist approach is unable to differentiate instances of borrowing or parody from cases in which the similarities were only coincidental. Only by investigating the actual author's working process can we differentiate these scenarios. 89

${ }_{86}$ Even though Stephen Davies subscribes to value maximization, he recognizes that irony, allusion, quotation, allegory, representation, and symbolism are all necessarily intentional. 'Authors' Intentions', 233-4. Some critics have argued against the appeal to intentions in such cases. See, for example, Monroe C. Beardsley, 'Intentions and Interpretations: A Fallacy Revived', in Michael J. Wreen and Donald M. Callen (eds.), The Aesthetic Point of View: Selected Essays (Ithaca, NY, 1982), 200, 203-5; Daniel O. Nathan, 'Irony, Metaphor, and the Problem of Intention', in Gary Iseminger (ed.), Intention and Interpretation (Philadelphia, PA, 2010), 183-202.

87 Vladimir Blok, Violonchel'noye tvorchestvo Prokof'yeva (Moscow, 1973), 129-30, argues that it is a parody of Lyuban's 'Bïvaitse zdarovii' (Be Healthy). It also displays similarity with his more political song 'Nash tost' (Our Toast). Mstislav Rostropovich, CD liner notes to Rostropovich: The Russian Years 1950-1974 (EMI, 1997), 28, claimed that it was a quotation of a song by Vladimir Zakharov, but Zakharov merely composed an arrangement of Lyuban's 'Bïvaitse zdorovï'.

88 Blok, Violonchel'noye tvorchestvo Prokof'yeva, 129; quoted in translation in Taruskin, 'Prokofiev's SymphonyConcerto, Op. 125', 16.

89 Taruskin, 'Prokofiev's Symphony-Concerto, Op. 125', 19. Linda Hutcheon, A Theory of Parody: The Teachings of Twentieth-Century Art Forms (Irbana, IL, 2000), 21-2, 34, argues against both formalist approaches like Gérard Genette, Palimpsests, trans. Claude Doubinsky and Channa Newman (Lincoln, NE, 1997), and those based solely on reader response, such as Joseph A. Dane, 'Parody and Satire: A Theoretical Model', Genre, 13 (1980), 145-59. 
In the case of Prokofiev's Op. 125, Simon Morrison observes a problem with a parodic interpretation. 'Given that these songs were sung as toasts to Stalin, Prokofiev would have been foolhardy to mock them in his concerto.' Instead, Morrison suggests that they were 'intended as a sincere (not cynical) response to [Prokofiev's] official censure in 1948, when he was instructed to increase the popular content of his scores.'90 Morrison's explanation fails to mesh with the actual features of Prokofiev's composition, Taruskin counters, pointing to the 'the grotesquerie of that middle section'. Taruskin argues that the passage was a 'Belorussian' variation of a theme from Prokofiev's Cello Concerto Op. 58 (1938).91 Its resemblance to various real and ersatz folk songs is pure coincidence. On account of being a plausible explanation not only of Prokofiev's intentions but also the passage's 'grotesquerie', Taruskin's argument would seem to be the stronger from an intentionalist perspective.

Intentions also play a role in moral evaluations. In response to the performance of John Adams and Alice Goodman's opera The Death of Klinghoffer at the Brooklyn Academy for Music in 1991, several critics, and eventually the Klinghoffer family, denounced the work as anti-Semitic. Chief target of these accusations was the opera's opening juxtaposition of an 'empathetic evocation of the intifada', and a portrayal of a suburban Jewish family that, aside from their singing, would not be out of place in a contemporary sitcom.92 Ten years later, just months after 9/11, Taruskin chimed in after the Boston Symphony cancelled their scheduled performances of choruses from the opera. Even though Adams and Goodman had removed the scene that had previously caused offense, replacing it with a 'Chorus of Exiled Jews' (complementing the 'Chorus of Exiled Palestinians'), Taruskin argued that the work still presents

90 Simon Morrison, 'Rostropovich's Recollections', Music \& Letters, 91 (2010), 83-90 at 88.

91 Taruskin, 'Prokofiev's Symphony-Concerto, Op. 125', 18, 19.

92 Edward Rothstein, “'Klinghoffer” Sinks into Minimal Sea', New York Times, 15 Sept. 1991; quoted in Robert

Fink, 'Klinghoffer in Brooklyn Heights', Cambridge Opera Journal, 17 (2005), 173-213 at 183. 
these groups in unequal terms. As evidence, he pointed to Adams's use of a musical aureolecomparable to that which Bach employed in representing the words of Jesus in the St Matthew Passion - in connection with the Palestinian terrorists but not their Jewish victims.93 Taruskin accused Adams not merely of portraying the Palestinians in an unjustly sympathetic light but of romanticizing terrorism.

Robert Fink has subsequently come to the work's defence, and has done so on intentionalist grounds. Anticipating being accused of the intentional fallacy, Fink justified his approach by observing that 'one cannot both levy the charge of conscious "anti-Semitism" - a crime of malicious intent - and demand that those who argue on the opposing side avoid the intentional fallacy. Detach this text from deliberate authorial intent (whether to defame or defend), and where is the transgression?'94 Nevertheless, Taruskin has dismissed Fink's argument on account that "it seeks to adjudicate the issue by examining "intention" (according to the old poietic fallacy) rather than reception.' 95

Taruskin and Fink's disagreement about the evidence appropriate to this case stems from a disagreement about what question they were answering. Taruskin was primarily concerned with the question Should we perform this work today? In mounting a case for 'forbearance', he also presented evidence that pertains to the question Does the work contain anti-Semitic content? Fink, by contrast, was primarily interested in the question '[W]hat were Adams and Goodman trying to do in Klinghoffer?'96 Specifically, did they intend to portray the Jewish characters in a prejudicial manner? Authorial intentions are, arguably, not of central importance to Taruskin's

93 Taruskin, 'Danger of Music', 172-3. The one exception Taruskin notes is the 'Aria of the Falling Body', sung by Klinghoffer after his death. 94 Fink, 'Klinghoffer in Brooklyn Heights', 204.

95 Taruskin, 'Danger of Music', 178.

96 Fink, 'Klinghoffer in Brooklyn Heights', 203. 
question about the advisability of performing this work today. But given Fink's concerns, his investigation of authorial intentions was justified.

My interest, in the present context, is in a moral evaluation of The Death of Klinghoffer, as presented at the Brooklyn Academy for Music in 1991. As such, I need to determine both whether an immoral act has been performed successfully and whether this performance (or its attempt) was intentional. Divergent answers are possible and most systems of law advocate different punishments for the different permutations of action and intention. In the case of Klinghoffer, one first needs to assess whether it possesses anti-Semitic content. By pointing to Adams and Goodman's stereotypical portrayal of the Rumors, in contrast to their heroic portrayal of the terrorists, I believe Taruskin makes this aspect of his case.

One also needs to investigate how this content got there: Who was responsible for its generation and was it the product of malice? 97 Since there is no evidence of sabotage or coercion, Adams and Goodman may be regarded as responsible for the relevant features of the score and libretto, respectively. Concerning the question of malicious intent, Fink does not make an effective argument in their defence. He regards Alma Rumor's assertion that Klinghoffer is a 'decent man', sung to 'a sweet and simple melodic line that sighs gently over the pulsating chords underneath', as a 'bald collective statement of authorial intent', demonstrating that ' $[\mathrm{w}] \mathrm{e}$ are not meant to identify with the terrorists'.98 Alma's remark has possible bearing on how we ought to regard Klinghoffer, not how we ought to regard the terrorists. And since she is a fictional character, Fink would have needed to follow up this observation with evidence that the authors intended us to adopt Alma's assessment of Klinghoffer as our own. Given that Adams

97 In other moral assessments, Taruskin displays an interest in intentions. See, for example, his discussion of Handel's Israel in Egypt in 'Afterword-What else?', in Joshua S. Walden (ed.), Representation in Western Music (Cambridge, 2013), 287-309 at 296.

98 Fink, 'Klinghoffer in Brooklyn Heights', 205. 
and Goodman cut this scene from the final version of the opera, that claim would be difficult to make.

Better evidence for the lack of malicious intent on Adams and Goodman's part would be their very decision to remove this scene after seeing that it caused offense. The lack of intent to cause harm does not absolve them of guilt, though it ought to cause us to judge them less harshly than if the prejudicial portions of the work were included with malice. Thus, while Adams and Goodman's intentions did not determine whether The Death of Klinghoffer is anti-Semitic, they remain germane to a moral evaluation of their work.99

Anti-intentionalism served the hermeneutic focus of the New Musicology but meshes less well with more recent New-Historicist impulses in the discipline. Musicologists' rejection of the autonomy of art is at odds with the motivating premises of anti-intentionalism, hypothetical intentionalism, and value maximization. The case of Owen Wingrave also points to methodological conflicts. Even the most historically situated of the foregoing positions, Levinson's version of hypothetical intentionalism, cannot explain musicologists' interest in composers' notes, sketches, correspondence, and statements in interviews.

Although musicology and analytic philosophy have historically operated in relative ignorance of each other, there is considerable congruence between the concerns of historical musicologists and those of moderate actual intentionalists. Both believe that musical works and performances cannot be neatly separated from the messy circumstances of their creation and place no limits on the kinds of evidence that may have bearing on one's interpretation. In the past

99 Noël Carroll cites a similar case in 'Anglo-American Aesthetics and Contemporary Criticism: Intentions and the Hermeneutics of Suspicion', Journal of Aesthetics and Art Criticism, 51 (1993), 245-52 at 249-50. Although Jules Verne did not intend his portrayal of the former slave Neb in The Mysterious Island (1874) to be racist, he did intend to represent $\mathrm{Neb}$ as childlike and naive, and these successfully realized intentions did result in a text that conveys racist attitudes. 
two decades, analytic aesthetics has undergone a shift away from formalism and towards more historically informed understandings of art. The time is ripe to re-examine what our respective disciplines have to say to one another. 